\title{
Transcription factor NF-кB as a potential biomarker for oxidative stress
}

\author{
R. van den Berg ${ }^{1,2 *}$, G. R. M. M. Haenen ${ }^{2}$, H. van den Berg ${ }^{1}$ and A. Bast ${ }^{2}$ \\ ${ }^{1}$ TNO Nutrition and Food Research, P.O. Box 360, 3700 AJ Zeist, Netherlands \\ ${ }^{2}$ Department of Pharmacology and Toxicology, Faculty of Medicine, University Maastricht, P.O. Box 616, 6200 MD \\ Maastricht, Netherlands
}

\begin{abstract}
There is increasing interest in the involvement of transcription factors, such as of the transcription factor NF- $\mathrm{BB}$ (nuclear factor- $\mathrm{KB}$ ), in the pathogenesis of various diseases. NF$\kappa \mathrm{B}$ is involved in the control of the transcription of a variety of cellular genes that regulate the inflammatory response by the production of cytokines, chemokines, cell adhesion molecules and acute phase proteins. The involvement of NF- $\kappa \mathrm{B}$ is especially of interest as it is activated by oxidative stress and its activation can be modulated by antioxidant compounds. The activation

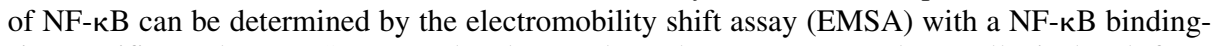
site-specific probe. EMSA can also be used on human mononuclear cells isolated from peripheral blood, which could make the assay applicable for clinical trials. The critical steps of the EMSA are discussed, addressing some pitfalls of the assay. The procedure that can be used to express NF- $\kappa \mathrm{B}$ activity in human subjects is evaluated. This offers the possibility to use $\mathrm{NF}-\kappa \mathrm{B}$ as a functional biomarker of oxidative stress as illustrated by several examples of in vitro and in vivo studies.
\end{abstract}

Reactive oxygen species: Antioxidants: NF-кB

Reactive oxygen species (ROS) are likely implicated in the pathogenesis of a wide variety of human diseases such as cancer and cardiovascular diseases (Halliwell \& Gutteridge, 1985; Bast, 1994). ROS are very reactive and may inflict direct damage to vital cell constituents such as lipids, proteins and DNA. ROS are also involved in the regulation of gene expression (Sen \& Packer, 1996). For a better understanding of ROS-associated disorders, recent studies have focused on the regulation of gene expression by intracellular reduction-oxidation (redox) state.

A well-defined transcription factor, nuclear factor (NF) $\kappa \mathrm{B}$, has been shown to be regulated by the intracellular redox state. Transcription factors are proteins that bind to regulatory sequences, usually in the $5^{\prime}$ upstream promoter region of target genes, to increase the rate of gene expression. This may affect protein synthesis, which could result in altered cellular function. Sen \& Baltimore (1986) first identified NF- $\mathrm{BB}$ as an apparently tissuerestricted B-cell nuclear factor that activated the immunoglobulin $\kappa$-light chain intron enhancer during Blymphocyte development. Since then, NF-кB has been identified in numerous cell types and is found to be activated by a wide variety of inducers, such as ultraviolet radiation, cytokines or bacterial and viral products (Siebenlist et al. 1994; Baeurele \& Baltimore, 1996).
The transcription factor NF- $\mathrm{kB}$ is of considerable interest to the field of free radical biology because it is activated by ROS and this enhanced activity can be modulated by antioxidants. Because ROS are generated under numerous pathological conditions, measurement of NF- $\kappa \mathrm{B}$ activation could provide important insight into the aetiology of these disorders and also offers the potential of NF- $\kappa \mathrm{B}$ as a functional biomarker for oxidative stress.

\section{Activation of $N F-\kappa B$}

In quiescent cells, NF- $\kappa \mathrm{B}$ is located in the cytosol as a dimer of protein components (p50/p65) bound to an

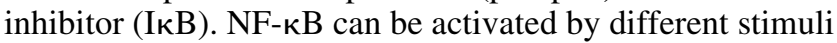
such as cytokines (e.g. tumour necrosis factor $\alpha$ (TNF- $\alpha$ ), interleukin 1 (IL-1)), phorbol esters, lipopolysaccharide (LPS) and in some cell types by hydrogen peroxide $\left(\mathrm{H}_{2} \mathrm{O}_{2}\right)$,

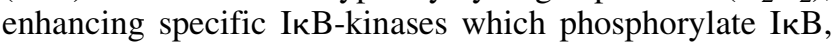
subsequently leading to a rapid ubiquination which results in degradation of IкB in the proteasome. Degradation of IкB uncovers nuclear localisation signals on the p65/p50 complex, resulting in a rapid translocation to the nucleus where it binds to specific $\kappa \mathrm{B}$ recognition elements in the promoter region of target genes (Fig. 1). In this way NF- $\kappa \mathrm{B}$ enhances the expression of inflammatory genes encoding

\footnotetext{
Abbreviations: COX-II, Cyclo-oxygenase-II; DNA, Deoxyribonucleic acid; EMSA, Electromobility shift assay; $\left[\gamma^{32} \mathrm{P}\right] \mathrm{ATP}$, Gamma-32-phosphor labelled adenosine triphosphate; $\mathrm{H}_{2} \mathrm{O}_{2}$, Hydrogen peroxide; ICAM, Intercellular adhesion molecule; IкB, Inhibitor-kappa B; IL-1, Interleukin-1; iNOS, Inducible nitric oxygen synthetase; LPS, Lipopolysaccharide; NF-кB, Nuclear factor-kappa B; PBMC, Peripheral blood mononuclear cells; PBS, Phosphate buffered saline; ROS, Reactive oxygen species; Sp1, Specific protein-1; TNF- $\alpha$, Tumour necrosis factor-alpha.

* Corresponding author: Dr R. van den Berg, fax +31 30 6944928, email R.vandenberg@voeding.tno.nl
} 


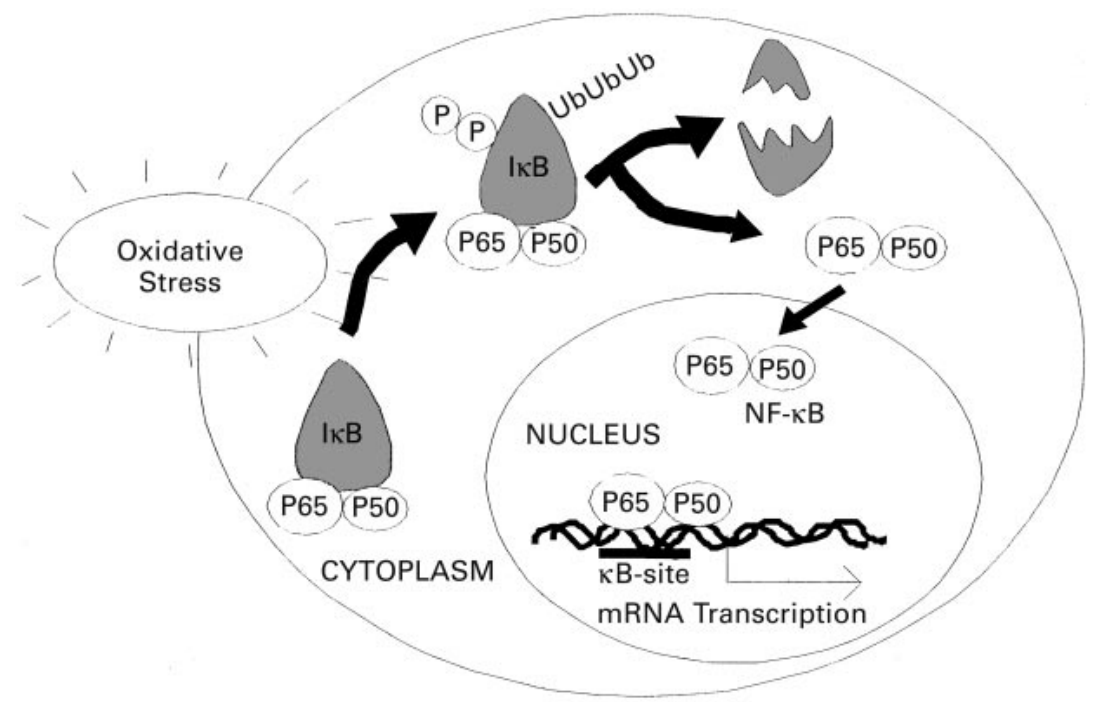

Fig. 1. Cascade of NF-кB activation. In unstimulated cells, NF-kB is located in the cytosol as a dimer of protein components (p50/p65) bound to an inhibitor ( $1 \kappa B$ ). NF-кB can be activated by oxidative stress, resulting in phosphorylation of $I_{\kappa} B$ by $I_{\kappa} B$-kinases, subsequently leading to a rapid ubiquination and degradation of $\mathrm{I}_{\kappa} \mathrm{B}$ in the proteasome. Degradation of $\mathrm{I}_{\kappa} \mathrm{B}$ uncovers nuclear localisation signals on the p65/p50 complex, resulting in a rapid translocation to the nucleus where it binds to specific $\mathrm{\kappa B}$ recognition elements in the promoter region of target genes.

for cytokines (e.g. IL-1), chemokines, growth factors, cell adhesion molecules (e.g. ICAM) or some acute phase proteins. NF- $\mathrm{BB}$ also regulates the expression of inflammatory enzymes, including the inducible form of nitric oxide synthetase (iNOS) (Xie et al. 1994) and inducible cyclo-oxygenase (COX-II) (Crofford et al. 1997). Inappropriate activation of NF- $\mathrm{KB}$ has been linked to inflammatory events associated with autoimmune arthritis, asthma, atherosclerosis, autoimmunodeficiency syndrome (AIDS), cancer and diabetic complications (Chen et al. 1999).

\section{Inhibition of $N F-\kappa B$ activation}

Recent in vitro studies have shown that NF-кB activation can be inhibited by antioxidants such as vitamin C (Bowie \& O'Neill, 1997), vitamin E (Islam et al. 1998) and flavonoids (Musonda \& Chipman, 1998) as well as the thiol containing compounds glutathione (Droge et al. 1994), $\alpha$ lipoic acid (Suzuki et al. 1992) and $N$-acetylcysteine (Schreck \& Baeuerle, 1994). Reduction of enhanced NF-кB activation by antioxidants indeed confirms the involvement of ROS in the activation process, but the exact redox sensitive sites, the localisation of antioxidant action, and signalling events responsible for NF- $\mathrm{KB}$ activation remains elusive. Many antioxidants inhibit NF- $\kappa \mathrm{B}$ by blocking upstream signalling that leads to phosphorylation of ІкВ. Antioxidants can potentially prevent oxidation of redoxsensitive cysteines in kinases or phosphatases (SchulzeOsthoff et al. 1995). Studies with glucocorticoids have shown that the anti-inflammatory effects of these compounds are achieved either by glucocorticoid receptor mediated blocking of NF-кB DNA binding (Scheinman et al. 1995) or enhancing the synthesis of IкB, which lead to inhibition of the nuclear translocation of NF-кB (Aupan et al. 1995).

\section{Measurement of NF- $\mathrm{kB}$ activation}

To clarify the role of NF- $\kappa \mathrm{B}$ in various aspects of cell function, inflammatory processes and pathologies, clinical studies have to be performed using NF- $\mathrm{BB}$ activity as a target for intervention with drugs or food components. Because of the involvement of NF- $\mathrm{BB}$ in numerous pathophysiological processes an unequivocal NF- $\kappa B$ determination might be useful in order to be able to use NF- $\mathrm{KB}$ as a functional biomarker.

The most widely applied method to establish NF-кB activation is the electromobility shift assay (EMSA). In EMSA, differences in concentration of NF- $\kappa$ B proteins that have been translocated to the nucleus can be detected. Because of the complications in transcriptional analysis in primary cell cultures or tissues it is important to point out the critical steps in EMSA, i.e. (1) cell isolation, (2) preparation of nuclear extracts, (3) NF- $\kappa \mathrm{B}$ determination by EMSA and (4) quantitative measurement of NF- $\mathrm{B}$ activity.

\section{Cell isolation}

The first step is to select the best available target cells. In vitro this is relatively easy since one can pick a cell line of the target organ or cells. In in vivo (human) experiments there are more restrictions because the number of target tissues is limited. EMSA using either alveolar macrophages obtained by fibreoptic bronchoscopy (Farver et al. 1998) or peripheral mononuclear cells obtained by venepuncture (Hofmann et al. 1999) are the two most commonly used 
(available) cell types. Peripheral cells have the advantage that they can be obtained relatively easily and are less sensitive to artefacts produced by stress during the isolation procedure.

During isolation it is essential to avoid false stress signals by working under standardised conditions at low temperatures $\left(4^{\circ} \mathrm{C}\right)$. To assess $\mathrm{NF}-\kappa \mathrm{B}$ activity in humans, $10-20 \mathrm{ml}$ of whole blood has to be used to prepare $1-10 \times$ $10^{6}$ peripheral blood mononuclear cells (PBMCs), immediately after venepuncture, by separation on a FicollIsopaque ${ }^{\circledR}$ gradient. After PBMC isolation it is advisable to isolate the nuclear proteins directly to circumvent freezing and thawing of the cells which introduces additional stress.

\section{Preparation of nuclear extracts}

Nuclear extracts are prepared by using $1-10 \times 10^{6}$ cells (freshly isolated or from cell culture). Again during the protein extraction it is important that all solutions are kept cold $\left(4^{\circ} \mathrm{C}\right)$ to avoid substantial protein degradation by proteases or false stress signals. Cells are washed three times in ice-cold phosphate-buffered saline (PBS) and lysed using an ice-cold lysis buffer as described by Hofmann et al. (1999). The use of $1 \%$ (v/v) mammalian protease inhibitor cocktail (Sigma, MO, USA) containing a mixture of 4-(2-aminoethyl)benzenesulphonyl fluoride, pepstatin A, trans-epoxysuccinyl-L-leucylamido(4-guanidino)butane, bestatin, leupeptin, and aprotinin is recommended to circumvent additional NF- $\mathrm{B}$ protein degradation. The cell suspension has to be incubated on ice for $15 \mathrm{~min}$ to complete the lysis of the cell membrane and centrifuged at $4^{\circ} \mathrm{C}$. This results in a pellet of nuclei. The supernatant is discarded and the nuclear pellet resuspended in an ice-cold (high salt) extraction buffer. To facilitate the extraction of the nuclear proteins, the nuclear suspension is shaken every $5 \mathrm{~min}$ for a total period of $20 \mathrm{~min}$ at $4^{\circ} \mathrm{C}$. The nuclear lysates are centrifuged at $4^{\circ} \mathrm{C}$ and the supernatant, containing the nuclear proteins, must immediately be collected and stored at $-80^{\circ} \mathrm{C}$ until further use. Protein concentrations can be determined according to the method of Bradford (BioRad, Veenendaal, The Netherlands), yielding sample concentrations of approximately $1 \mu \mathrm{g} / \mathrm{ml}$. Nuclear extracts should not be thawed more than twice and are stable for one year at $-80^{\circ} \mathrm{C}$.

\section{$N F-\kappa B$ determination by EMSA}

EMSA is a traditional and simple method to determine the inducible (p65/50) and the constitutive (p50/50) NF- $\mathrm{KB}$ in nuclei. A double-stranded NF- $\mathrm{NB}$ oligonucleotide $\left(5^{\prime}-\mathrm{GAT}\right.$ CCA AGG GGA CTT TCC ATG GAT CCA AGG GGA CTT TCC AGT-3', Isogen, Maarssen, The Netherlands) containing a tandem repeat of the consensus sequence for the NF- $\mathrm{B}$ binding site (-GGGGACTTTCC-) or sp1 (5'...ATT CGA TCG GGG CGG GGC GAG C...3', Promega, MD, USA) is incubated with $\left[\gamma^{-}{ }^{32} \mathrm{P}\right] \mathrm{ATP}$ (Amersham Pharmacia, Roosendaal, The Netherlands) in the presence of T4-polynucleotide kinase (Beuringer, Mannheim, Germany) at $37^{\circ} \mathrm{C}$ for $45 \mathrm{~min}$. The ${ }^{32} \mathrm{P}$ end labelled oligonucleotide is separated from the non-incorporated
${ }^{32} \mathrm{P}$ by a Sephadex G-50 (Sigma, MO, USA) column filtration. Incubation of $1 \mathrm{ng}$ of radiolabelled NF- $\kappa \mathrm{B}$ oligonucleotide with $10 \mu \mathrm{g}$ of nuclear extract containing the NF- $\kappa \mathrm{B}$ proteins for $20 \mathrm{~min}$ at room temperature results in binding of NF- $\kappa \mathrm{B}$ proteins to the oligonucleotide. Such a binding results in retardation ('shift') of the electromobility of the oligonucleotide on a $5 \%$ non-denaturating polyacrylamide gel (Biozym, Landgraaf, The Netherlands). These shifts can be visualised by phosphor imaging using a Cyclone (Packard, Meriden, USA) phosphor-imager. For the DNA binding reaction it is important that the volume of high-salt extraction buffer is the same in each binding assay, to avoid differences in binding kinetics of the protein to the oligonucleotide This can be achieved by diluting the more concentrated nuclear protein extracts in the same extraction buffer. Specificity of NF-кB DNA binding is ascertained by competition with a 150 -fold molar excess of unlabelled consensus oligonucleotides, displacing all radiolabelled oligonucleotides, resulting in a disappearance of all NF-кB complexes. Characterisation can be done by so called 'supershifting' using specific antibodies for the NF-кB subunits p65 and p50 proteins (Janssen \& Sen, 1999).

\section{Quantitative measurement of $\mathrm{NF}-\kappa \mathrm{B}$ activity}

To quantitate the NF-кB signal, a constant amount of HeLa nuclear extract is included on each gel as a control. Alternatively, the transcription factor sp1 can be used to quantitate the NF- $\mathrm{BB}$ signal, including the extraction quality of the nuclear extract. The intensity of the resulting NF- $\kappa \mathrm{B}$ signals are determined by densitometry (Optiquant) for each gel. Sp1 is widely regarded as a housekeeping-type of nuclear transcription factor with constitutive activity and ubiquitous occurrence. The constant expression levels of $\mathrm{sp} 1$ can therefore be used to observe an increase in NF- $\kappa$ B activity.

To compare the results obtained from different gels, the $\mathrm{NF}-\kappa \mathrm{B}$ signal has to be related either to the sp1 signal of the same sample or to the NF- $\kappa \mathrm{B}$ signal of the HeLa extract that is run as a control on each gel. The densitometric value for the NF- $\kappa \mathrm{B}$ signal can then be converted into $\mathrm{sp} 1$ equivalents or HeLa equivalents/10 $\mu \mathrm{g}$ protein.

\section{NF- $\kappa$ B as a potential 'new' biomarker of oxidative stress?}

Regulation and control of $\mathrm{NF}-\kappa \mathrm{B}$ activation can be a powerful therapeutic strategy for reducing tissue damage or other complications as a consequence of the releases of inflammatory mediators. Therefore, NF- $\kappa \mathrm{B}$ activity in humans is a 'new' target of interest to establish increased activity in several inflammatory diseases.

Recent studies show that NF- $\kappa \mathrm{B}$ binding activity is increased in patients suffering from leprosy (Zea et al. 1998), sepsis (Böhrer et al. 1997), unstable angina pectoris (Ritchie, 1999) and diabetic nephropathy (Hofmann et al. 1999). The study with diabetic patients performed by Hofmann et al. showed that compared to the control group, the patients with diabetes mellitus and albuminuria had an increased NF- $\mathrm{KB}$ activity. More interestingly was the fact that when patients with diabetic nephropathy were treated 

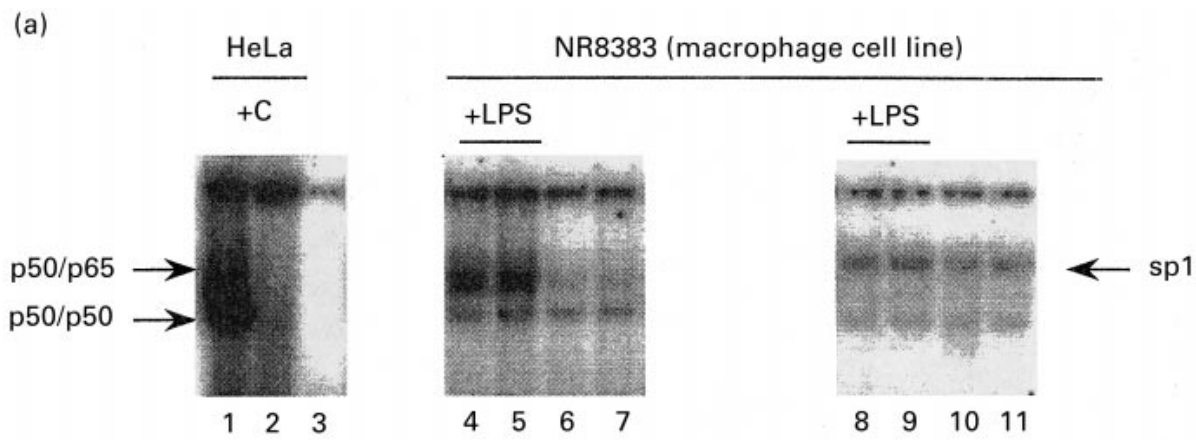

(b)

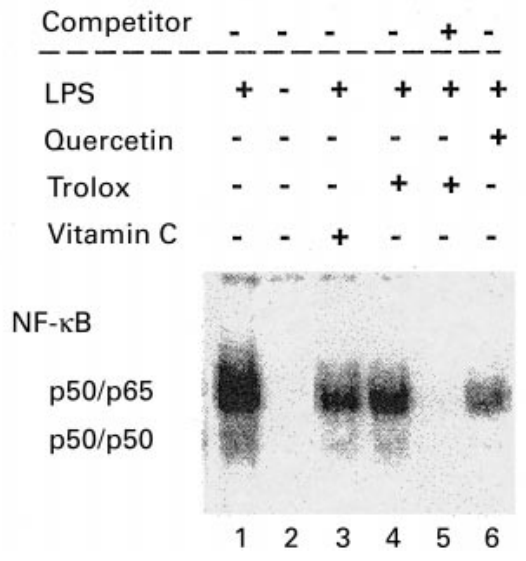

Fig. 2. NF-kB and sp1 activity of rat macrophages with LPS. (a) Nuclear extracts were prepared in duplicate from cells treated with $0 \cdot 1 \mu \mathrm{g} / \mathrm{ml}$ lipopolysaccharide (LPS) (lanes 4, 5, 8 and 9) or without LPS (lanes 6, 7, 10 and 11). Nuclear extracts were incubated with either the NF-кB probe (lanes 1-7) or the sp1 probe (lanes 8-11), followed by EMSA. As a control HeLa nuclear extract without (lane 1), with 150-fold excess competitor $(+\mathrm{C}$, lane 2$)$ and free probe (lane 3$)$ is used. (b) Nuclear extracts were prepared from cells treated with $0.1 \mu \mathrm{g} / \mathrm{ml}$ LPS (lane 1$)$; LPS

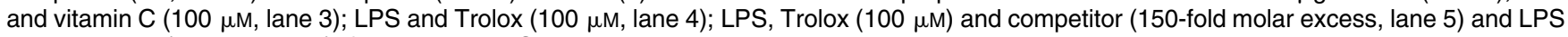
and quercetin $(10 \mu \mathrm{M}$, lane 6$)$, followed by EMSA. Free probe is shown in lane 2.

for three days with $600 \mathrm{mg}$ with the antioxidant $\alpha$-lipoic acid, this resulted in a $38 \%$ decrease of NF- $\kappa \mathrm{B}$ activity. Preliminary results of a study with heavy smoking subjects and the effect of a vegetable/fruit concentrate also showed that the NF- $\mathrm{KB}$ activity is increased in these subjects (van den Berg et al. in press), suggesting that NF- $\kappa \mathrm{B}$ activity could be used as a biomarker of oxidative stress.

\section{$N F-\kappa B$ as biomarker of oxidative stress in vitro}

Fig. 2 shows an example of an in vitro study using sp1 as a standard. The experiment demonstrates that NF- $\kappa \mathrm{B}$ binding activity is increased in a rat macrophage cell line (NR8383) by a 1 hour incubation with $0 \cdot 1 \mu \mathrm{g} / \mathrm{ml}$ LPS (Escherichia coli, Sigma, St Louis, MO, USA) at $37^{\circ} \mathrm{C} / 5.0 \% \mathrm{CO}_{2}$ (Fig. 2a). LPS are fragmental membranes of bacteria that activate the macrophage cell line. The transcription factor $\mathrm{NF}-\kappa \mathrm{B}$ concentration is indeed increased, whereas LPS does not influence the sp1 binding activity in NR8383 cells. Sp1 can be used both as a control to assess the efficiency of the nuclear extraction and as an internal standard to relate the NF- $\kappa \mathrm{B}$ concentration to. Pre-incubation of the cells with the antioxidants vitamin $\mathrm{C}(100 \mu \mathrm{M}$, Merck, Darmstadt, Germany), Trolox (100 $\mu \mathrm{M}$, Aldrich, Milwaukee, WI, USA) and quercetin (10 $\mu \mathrm{M}$, Fluka, Bio Chemica,
Buchs, Switzerland) followed by a $1 \mathrm{~h}$ incubation with $0 \cdot 1 \mu \mathrm{g} / \mathrm{ml}$ LPS resulted in a decrease in NF- $\kappa \mathrm{B}$ binding activity (Fig. 2b). This confirms that antioxidants can influence the activity of NF- $\mathrm{B}$ in the nucleus of macrophages and that drugs or food components can be screened for potential antioxidant activity.

\section{$N F-\kappa B$ as biomarker of oxidative stress in vivo}

The determination of the basal activity of PBMCs of healthy subjects, expressed as sp1 equivalents, is shown in Fig. 3 ( $a$ and b). The EMSA (Fig. 3a) clearly shows two specific bands; the upper band represents the inducible p65/ 50 complex and the lower band the constitutive p50/50 complex. There is a very low sp1 activity and when NF-кB is expressed as sp1 equivalents only a $50 \%$ increase in NF$\kappa \mathrm{B}$ activation is found (Fig. 3b).

The use of sp1 activity to relate $N F-\kappa B$ activity to is theoretically very elegant, because it includes the extraction efficiency. The nuclear concentration of $\mathrm{sp} 1$ is constant in healthy volunteers, but in sarcoidosis a distinct increase in sp1 binding activity is seen (Drent et al. in press). This limits the use of sp1 and therefore the HeLa nuclear extract is used as an external standard to relate NF- $\mathrm{NB}$ activity to (Fig. 3c). 
(a)

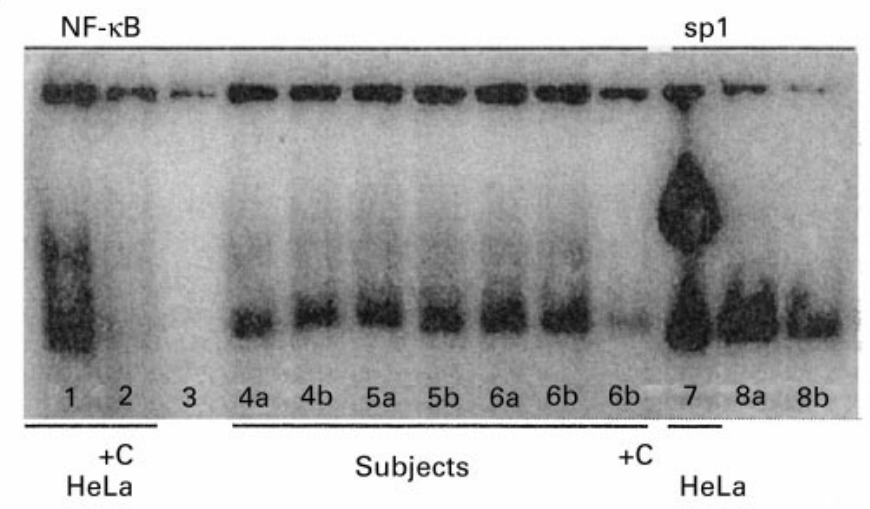

(b)

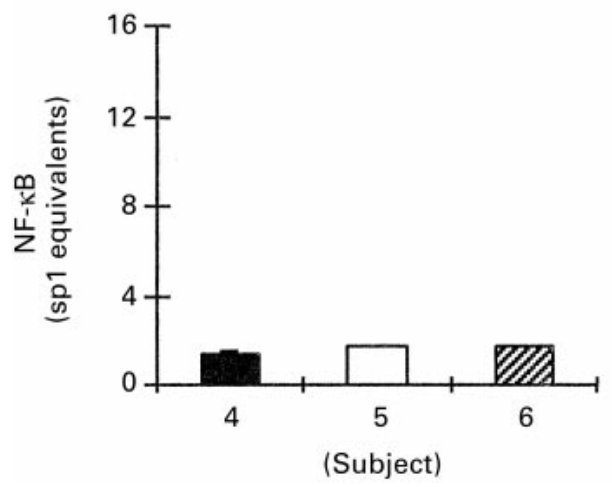

(c)

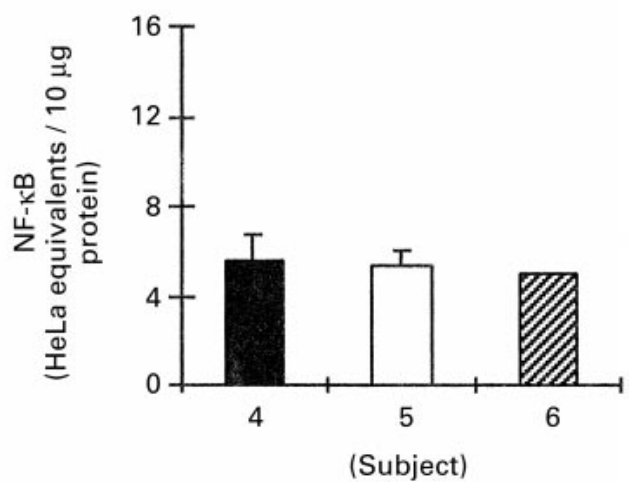

Fig. 3. Basal NF-kB and sp1 activity in peripheral blood mononuclear cells of healthy subjects. (a) Nuclear extracts from PBMCs of three healthy subjects were prepared in duplicate, followed by EMSA with the NF-кB probe $(4 a+4 b, 5 a+5 b$ and $6 a+6 b)$. Lane 1 represents the HeLa nuclear extract, lane 2 HeLa plus a 150-fold molar excess competitor $(+C)$ and lane 3 the free probe. A nuclear extract from PBMCs of one of the healthy subjects prepared in duplicate, followed by EMSA with the sp1 probe (lane $8 a+8 b)$. Lane 7 represents the control HeLa nuclear extract with the sp1 probe. The NF-kB activity is related either to the transcription factor sp1 (b) or to the HeLa nuclear extract (c).

We recently examined the NF- $\kappa$ B activity in sarcoidosis, a multiorgan disorder characterised by the formation of aggregates of inflammatory cells within the affected organ. It appeared that in the PBMC of sarcoidosis patients the activity of NF-kB $(8.4 \pm 2.5 \mathrm{HeLa}$ equivalents $/ 10 \mu \mathrm{g}$ protein, mean $\pm \mathrm{SD}$ ) is twice as high as that in healthy subjects $(4.4 \pm 0.7 \mathrm{HeLa}$ equivalents $/ 10 \mu \mathrm{g}$ protein, mean \pm SD) (Fig. 4). The enhanced NF-кB activity has major implications for unravelling the aetiology of the disease. Remarkably, the NF-кB activity was not lower in patients receiving glucocorticosteroids, which coincides with the limited efficacy of these drugs in this disease. Apparently, new avenues for treatment of sarcoidosis need to be found. Antioxidants may possibly provide an alternative for the glucocorticosteroids in the treatment of the disease.

\section{Conclusion and perspectives}

The redox-controlled transcription factor NF- $\kappa \mathrm{B}$ has for some years been recognised as an important mediator in the regulation of the inflammatory genes and is likely to be involved in the pathophysiology of several diseases. Using the EMSA procedure as described in this overview, measurement of NF- $\kappa \mathrm{B}$ offers the possibility to evaluate both the activation of NF- $\mathrm{KB}$ various pathologies, as well as the strategy used to reduce NF- $\mathrm{B}$ activation.

The function of NF- $\mathrm{KB}$ in clinical studies can be assessed in isolated human PBMCs. However, care has to be taken to avoid false stress signals or early degradation of nuclear proteins during the isolation procedure. This can be achieved by using protease inhibitors, working at low temperatures, as fast as possible, following a standardised protocol.

To compare results obtained from different gels or different studies, a standard has to be used. Using another transcription factor, such as the 'housekeeping' transcription factor sp1, as a standard has the advantage that also a correction for the loss of nuclear proteins during the isolation procedure can be made. However, we found that the activity of transcription factor $\mathrm{sp} 1$ is altered during sarcoidosis (Drent et al. in press), which limits the use of 

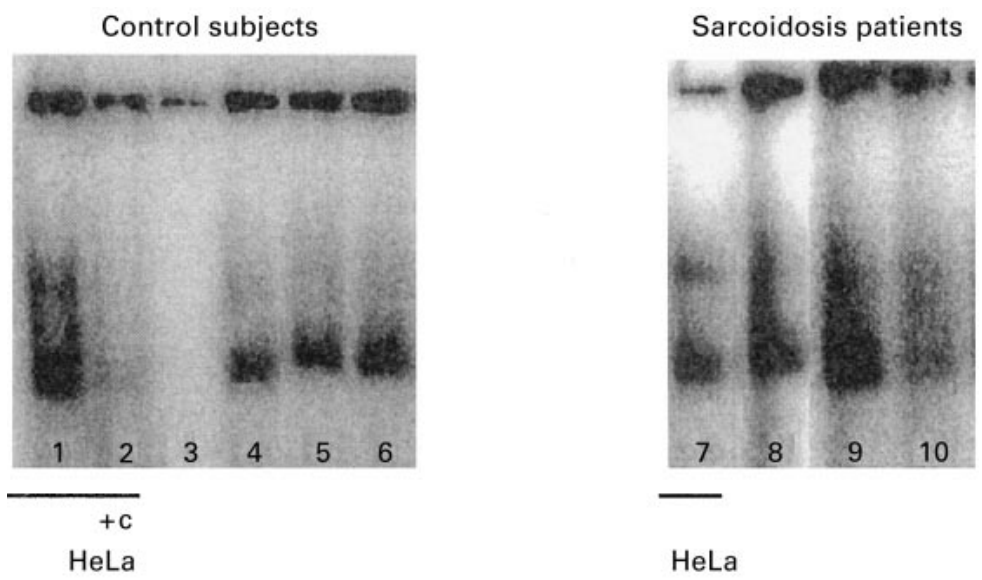

HeLa

HeLa

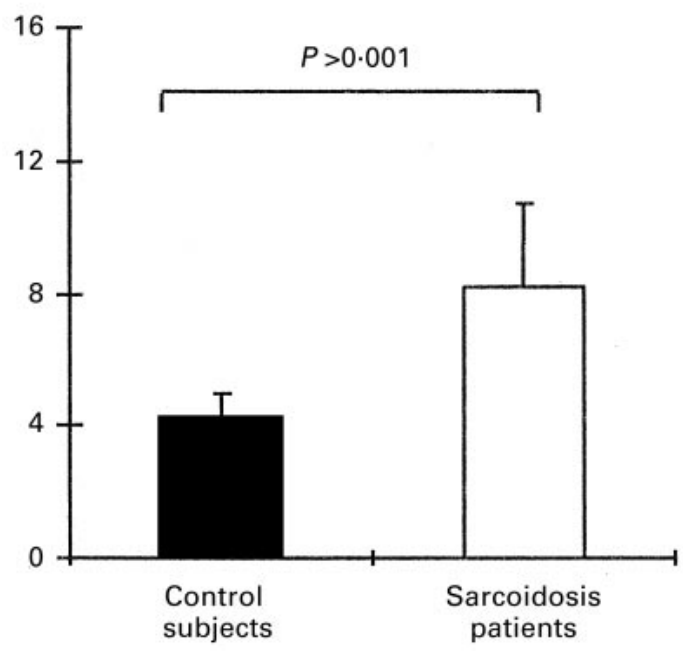

Fig. 4. NF-кB activity in peripheral blood mononuclear cells (PBMCs) of patients without and with sarcoidosis expressed as HeLa equivalents/10 $\mu \mathrm{g}$ protein. Nuclear extracts from PBMCs of three control subjects (lanes 4, 5 and 6) and three sarcoidosis patients (lanes 8, 9 and 10) were prepared, followed by EMSA. Lanes 1 and 7 represent the HeLa nuclear extract, lane 2 HeLa plus a 150-fold molar excess competitor $(+C)$ and lane 3 the free probe. The NF-кB activity is related to the HeLa nuclear extract.

sp1 as a standard. Instead of a transcription factor we used a commercially available HeLa nuclear extract (Promega, Madison, USA). This nuclear extract could serve as a control to check the EMSA, as well as a standard to which the NF- $\kappa \mathrm{B}$ signal on each gel is related. Unfortunately, no correction for the extracting efficiency is made when the HeLa extract is used.

Several clinical studies have shown that NF- $\mathrm{B}$ binding activity is increased in different diseases (Böhrer et al. 1997; Zea et al. 1998; Hofmann et al. 1999; Ritchie, 1999). Indications have been found that antioxidants can inhibit $\mathrm{NF}-\kappa \mathrm{B}$ activation both in vitro and in vivo (Hoffmann et al. 1999). Our observations with EMSA on a macrophage cell line, healthy subjects and sarcoidosis patients confirm that NF- $\kappa \mathrm{B}$ could be used as a marker of oxidative stress. However, more experiments are needed to validate this marker and to fully unveil the role of this important nuclear factor in pathogenesis and the effect of antioxidants on human health.

Fundamental research in this rapidly developing area is focused on elucidating the exact role of NF- $\mathrm{NB}$ in oxidative stress related processes and the molecular mechanism of action of antioxidants. This may lead to new pharmacotherapeutic strategies. Applied research is directed towards the development of new probes and methods for evaluating the role of $N F-\kappa B$ and the efficacy of clinical treatment schedules.

\section{References}

Aupan N, Di Donato J, Rosette C, Helmberg A \& Karin M (1995) Immunosupression by glucocorticoids: inhibition of NF-кB activity through induction of IкB synthesis. Science 270, 286290. 
Baeurele AP \& Baltimore D (1996) NF- $\kappa$ B: ten years after. Cell 87, 13-20.

Bast A (1994) Antioxidant pharmacotherapy. Drug News \& Perspectives 7, 465-472.

Böhrer H, Qui F, Zimmermann T, Zhang Y, Jllmar T, Männel D, Böttiger BW, Stern DM, Waldherr R, Saeger HD, Ziegler R, Bierhaus A, Martin E \& Nawroth P (1997) Role of NF-кB in the mortality of sepsis. Journal of Clinical Investigation 100, 972-985.

Bowie A \& O'Neill LAJ (1997) Vitamin C inhibits NF-кB activation in endothelial cells. Biochemical Society Transactions 25, 131S.

Chen F, Castranova V, Shi X \& Demers LM (1999) New insights into the role of nuclear factor- $\mathrm{B}$, a ubiquitous transcription factor in the initiation of diseases. Clinical Chemistry 45, 7-17.

Crofford LJ, Tan B, McCarthy CJ \& Hla T (1997) Involvement of nuclear factor $\mathrm{\kappa B}$ in the regulation of cyclooxygenase-2 expression by interleukin-1 in rheumatoid synoviocytes. Arthritis and Rheumatism 40, 226-236.

Drent M, van den Berg R, Haenen GRMM, van den Berg H, Wouters EFM \& Bast A (2001) NF- $\kappa$ B activation in sarcoidosis. Sarcoidosis in press.

Droge W, Schulze-Osthoff K, Mihm S, Galter D, Schrenck H, Eck HP, Roth S \& Gmunder H (1994) Functions of glutathione and glutatione disulfide in immunology and immunopathology. FASEB Journal 8, 1131-1138.

Farver CF, Raychaudhuri B, Buhrow LT, Connors MJ \& Thomassen MJ (1998) Constitutive NF-кB levels in human alveolar macrophages from normal volunteers. Cytokine 10, $868-871$.

Halliwell B \& Gutteridge JMC (1985) Free Radicals in Biology and Medicine, Oxford: Clarendon Press.

Hofmann MA, Schiekofer S, Isermann B, Kanitz M, Henkels M, Joswig M, Treusch A, Morcos M, Weiss T, Borcea V, Abdel Kalec AKM, Amiral J, Trischler H, Ritz E, Wahl P, Ziegler R, Bierhaus A \& Nawroth PP (1999) Peripheral blood mononuclear cells isolated from patients with diabetic nephropathy show increased activation of the oxidative-stress sensitive transcription factor NF-кB. Diabetologia 42, 222-232.

Islam KN, Devaraj S \& Jialal I (1998) $\alpha$-Tocopherol enrichment of monocytes decreases agonist-induced adhesion to human endothelial cells. Circulation 98, 2255-2261.

Janssen YMW \& Sen CK (1999) Nuclear factor $\kappa B$ activity in response to oxidants and antioxidants. Methods in Enzymology 300, 363-374.

Musonda CA \& Chipman JK (1998) Quercetin inhibits hydrogen peroxide $\left(\mathrm{H}_{2} \mathrm{O}_{2}\right)$-induced NF- $\mathrm{KB}$ DNA binding activity and DNA damage in HepG2 cells. Carcinogenesis 19, 1583-1589.

Ritchie ME (1999) Nuclear factor-кB is selectively and markedly activated in humans with unstable angina pectoris. Circulation 98, 1707-1713.

Scheinman RI, Gualberto A, Jewell CM, Cidlowski JA \& Balwin AS Jr (1995) Characterization of mechanisms involved in transrepression of NF- $\kappa \mathrm{B}$ by activated glucocorticoid receptors. Molecular Cell Biology 15, 943-953.

Schreck R \& Baeuerle PA (1994) Assessing oxygen radicals as mediators in activation of inducible eukaryotic transcription factor NF-kappa B. Methods in Enzymology 234, 151-163.

Schulze-Osthoff K, Los M \& Baeuerle PA (1995) Redox signalling by transcription factors NF- $\kappa \mathrm{B}$ and AP-1 in lymphocytes. Biochemical Pharmacology 50, 735-741.

Sen CK \& Packer L (1996) Antioxidants and redox regulation of gene transcription. FASEB Journal 10, 709-720.

Sen R \& Baltimore D (1986) Multiple nuclear factors interact with the immunoglobulin enhancer sequences. Cell 46, 705-716.

Siebenlist U, Franzoso G \& Brown K (1994) Structure, regulation and function of NF-кB. Annual Review of Cell Biology 10, 405-455.

Suzuki YJ, Aggarwal BB \& Packer L (1992) Alpha-lipoic acid is a potent inhibitor of NF- $\mathrm{KB}$ activation in human $\mathrm{T}$ cells. Biochemical and Biophysical Research Communictions 189. 1709-1715.

van den Berg R, van Vliet T, Broekmans WMR, Cnubben NHP, Vaes WHJ, Rosa L, Haenen GRMM, Bast A \& van den Berg H (2001) No effect of a vegetable/fruit concentrate with a high antioxidant capacity on biomarkers of antioxidant status in male smokers. Journal of Nutrition in press.

Xie QW, Kashiwabara Y \& Nathan C (1994) Role of transcription factor $\mathrm{NF}-\kappa \mathrm{B} / \mathrm{Rel}$ in induction of nitric oxide synthetase. Journal of Biological Chemistry 269, 4705-4708.

Zea AH, Ochoa MT, Ghosh P, Longo DL, Alvord WG, Valderrama L, Falabella R, Harvey LK, Saravia N, Moreno LH \& Ochoa AC (1998) Changes in expression of signal transduction proteins in $\mathrm{T}$ lymphocytes of patients with leprosy. Infection and Immunity 66, 499-504. 